Article available at nttp://www.parasite-Journal.org or nttp://dx.dol.org/10.1051/parasite/1998054381

\title{
Sandflies on the island of Corfu, Greece
}

\author{
PAPADOPOULOS B."* \& TSELENTIS Y.*
}

\section{Summary :}

The island of Corfu is an endemic area of human leishmaniasis, mainly visceral and secondly cutaneous. In August 1996, a survey of phlebotomine sandflies was conducted throughout the whole island. Using castor-oil paper traps, a total of 2,615 sandflies were caught. The following species were identified: 450 $(17.21 \%)$ Phlebotomus neglectus, $213(8.15 \%)$ P. tobbi, 129 (4.93\%) P. perfiliewi, 12 (0.46\%) P. sergenti, 17 (0.42\%) P. simici, $4(0.15 \%)$ P. papatasi, $999(38.20 \%)$ Sergentomyia minuta and $797(30.48 \%)$ S. dentata. Among the potential vectors of leishmania spp, $P$. neglectus, $P$. tobbi and $P$. perfiliewi, were the most widespread species on the island. However, a decrease of the population density of sandflies compared to previous entomological studies was observed.

KEY WORDS : Sandflies, Greece.
Résumé : Les phlÉbotomes de l'île de CORfu, Grèce

L'île de Corfu est une région endémique de leishmaniose humaine viscérale et secondairement de leishmaniose cutanée. En aoưt 1996, une étude sur les phlébotomes a été entreprise dans toute lîle. Au total, 2615 phlébotomes ont été capturés par la méthode des pièges adhésifs. Les espèces suivantes ont été identifièes: 450 (17,21\%) Phlebotomus neglectus, $213(8,15 \%)$ P. tobbi, 129 $(4,93 \%)$ P. perfiliewi, $12(0,46 \%)$ P. sergenti, $11 \quad 10,42 \%)$ P. simici, $4(0,15 \%) P$. papalasi, $999(38,20 \%)$ Sergentomyia minuta et $797(30,48 \%) \mathrm{S}$. dentata. Parmi les vecteurs potentiels de Leishmania spp., P. neglectus, P. tobbi et P. perfiliewi sont les espèces les plus répandues. Toulefois, une baisse de la densité des populations de phlébotomes par rapport aux études entomologiques précédentes a été observée.

MOTS CIÉS : Phlébotomes, Grèce
T he prefecture ${ }^{1}$ of Corfu, consisting of the island of Corfu and some surrounding small islands, is one of the four prefectures of the Ionian Islands lying to the west of mainland Greece. It is an endemic area of human leishmaniasis, mainly visceral and secondly cutaneous. According to the data of the Greek Ministry of Health, during the period 19511995, 56 cases of visceral leishmaniasis (VL) and 22 cases (12 of them in 1951) of cutaneous leishmaniasis (CL) were recorded in this prefecture. The incidence of leishmaniasis in dogs, considered to be the domestic reservoir host of VL in the Mediterranean region, is much higher. During the last nine years (1988-1996) for which detailed statistics are available from the Office of Animal Health of the Greek Ministry of Agriculture, 297 canine cases were reported by the local Veterinarian Services.

Leishmania infantum, the causative agent of zoonotic $\mathrm{VL}$ and sporadic cases of CL, has been isolated in Corfu from a human, a dog and a sandfly. In 1981, Tzamouranis et al. (1984) succeeded in isolating and typing $L$. infantum from a human and a dog that had overt leishmaniasis, while in 1987, Léger et al. (1988) isolated a parasite from Pblebotomus neglectus, which was found by isoenzyme characterization to be indistinguishable from L. infantum zymodeme MON1 (= LON49).

In an early study conducted before the second World War, Stephanides (1940) observed that P. papatasi was the most abundant sandfly species in the human habitations of Corfu. Later, during the period 19791981 , in a large scale entomological survey conducted on the island by the team of Prof. N. Léger, sandflies of eight different species were captured (MaduloLeblond, 1983; Pesson et al., 1984).

In this paper we present the results of a massive sampling of sandflies throughout the island of Corfu conducted in August 1996.

\footnotetext{
Prefecture : administrative division of the country.
}

* Laboratory of Clinical Bacteriology, Parasitology, Zoonoses and Geographical Medicine, Faculty of Medicine, University of Crete, P.O. Box 1393, Iraklion Crete, Greece.

Correspondence: Dr. B. Papadopoulos.

Tel.: 081 394076-394743-394801 - Fax: 081394408.

E-mail: byron@edu.uch.gr

\section{STUDY AREA}

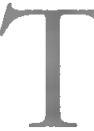
he island of Corfu $\left(592 \mathrm{~km}^{2}, 104,781\right.$ inhabitants) is the northernmost large island of the Ionian sea. In terms of administration, this island with other surrounding small islands form the 


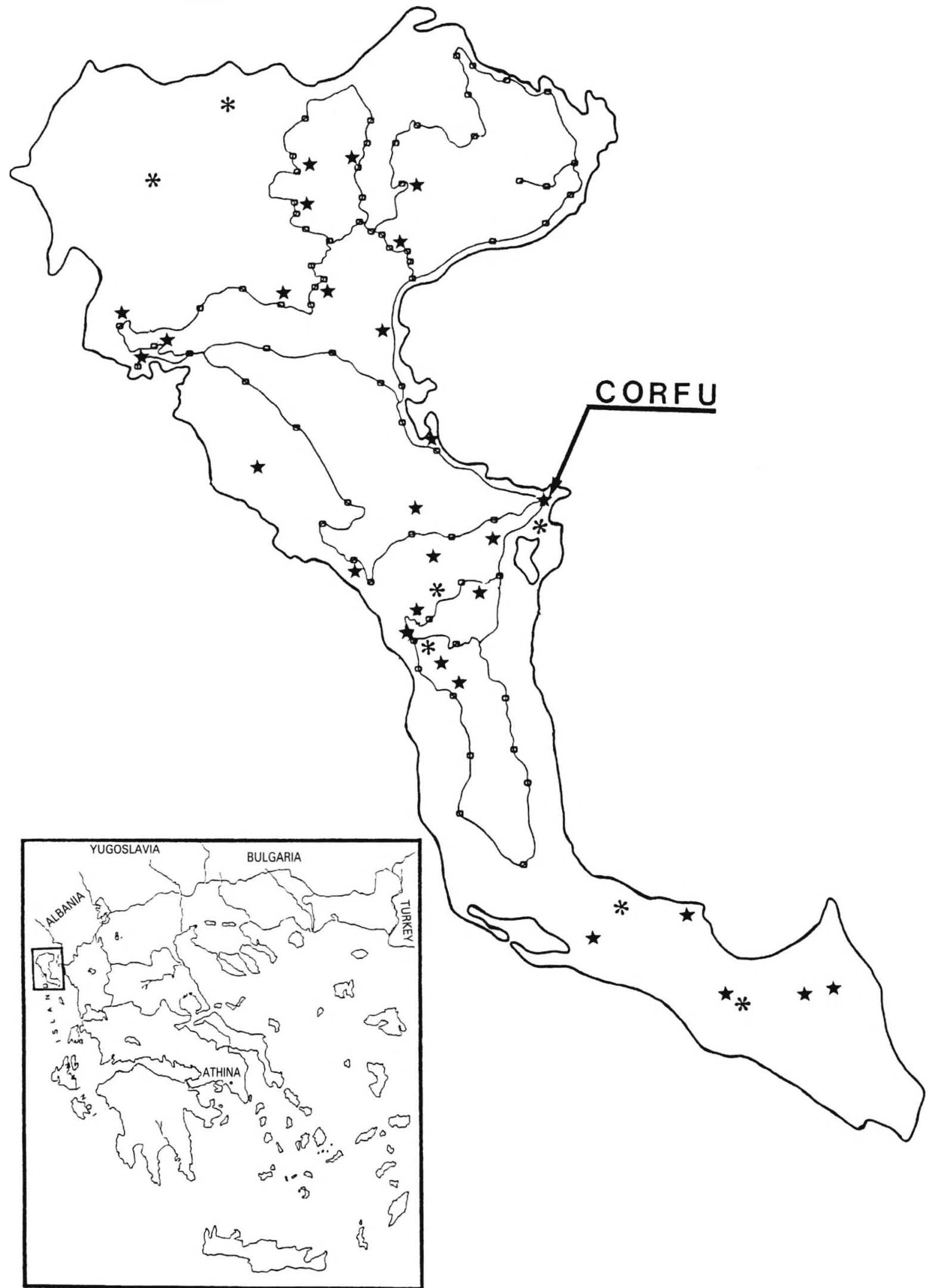

Fig. 1. - The island of Corfu with the stations in which the entomological survey was carried out ( 0 ) and sites from where human VL $(\star)$ and CL $(*)$ cases were reported during the period 1951-1995. 
prefecture of Corfu (642 km², 107,592 inhabitants). Its capital is the city of Corfu (31,359 inhabitants) situated on the west coast of the island. The island of Corfu is situated in the north-west part of Greece, opposite the region of Hepirus in the Greek mainland and Albania, between $39^{\circ} 22^{\prime}$ and $39^{\circ} 49^{\prime}$ north latitude and $19^{\circ} 38^{\prime}$ and $20^{\circ} 08^{\prime}$ east longitude (Fig. 1). The island is about $62 \mathrm{~km}$ long and $28 \mathrm{~km}$ wide in its northern part, reduced to $3.5 \mathrm{~km}$ in its narrowest southern part. Most of the island is of low altitude $(<100 \mathrm{~m})$. Mount Pantocrator, $906 \mathrm{~m}$ in altitude, in the north is its highest point. There is also a mountain ridge, with a maximum altitude of $576 \mathrm{~m}$, in the central-southern region. The rest of the island is flat to hilly. The whole island belongs to the attenuated mesomediterranean type of the mediterranean bioclimate (Mavrommatis, 1980). It is located on the January isotherm of $10^{\circ} \mathrm{C}$ and the July isotherm of $25.5^{\circ} \mathrm{C}$. The relative humidity is relatively high during the entire year (65-75\%) and the mean annual precipitation is $1,150 \mathrm{~mm}$.

The entomological survey was conducted along transects at 72 stations, mainly in the north and the central part of the island (Fig. 1). The stations were located at points whose altitude ranged from 20 to $680 \mathrm{~m}$.

\section{MATERIALS AND METHODS}

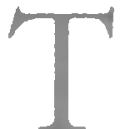

he entomological survey was carried out between August 16 and August 23, 1996, in 72 stations on transects throughout the island (Fig. 1). Sandflies were caught using castor-oil treated paper sheets (A4 format photocopy papers). A total of 1,170 castor-oil treated paper sheets were set and 1,125 of them were recovered (losses $3.85 \%$ ).
The sticky traps (10 to 30 traps/station) were placed into any potential sandfly breeding or resting site (holes or cracks in dry walls or rocks; spaces in stone walls; pipes of buildings or gardens). The papers were left in place for four days. The specimens were then picked up with a fine paint-brush, washed in $90 \%$ ethanol, cleared and mounted in Marc-André solution for identification, which was made according to the descriptions of Léger et al. (1986).

In order to estimate the relative densities of the sandfly species in the different stations, the number of sandflies collected per 100 paper traps $(\mathrm{sf} / 100 \mathrm{pt})$ per station was calculated. Stations with $<25 \mathrm{sf} / 100$ pt are considered of low density for the species in question, stations with $25-100 \mathrm{sf} / 100 \mathrm{pt}$ of middle density and stations with $>100 \mathrm{sf} / 100 \mathrm{pt}$ of high density.

\section{RESULTS}

A total of 2,615 sandflies were collected during August 1996. Table I shows the species identified, their total number, their relative density (number of sandflies per 100 paper traps), their percent of total, the number of males and females and the proportion of females for each species, as well as the number of localities in which they were found and their percent of total.

All but nine stations were positive for sandflies. About $1 / 3$ of the captures were Phlebotomus spp. and the rest $2 / 3$ Sergentomyia spp. (Table I). Almost all samples of Phlebotomus spp. belong to the subgenus Larroussius, $P$. neglectus being the most abundant and widespread. For Sergentomyia spp. almost equal numbers of males and females were captured, while for Phlebotomus spp. the sex ratio was strongly in favor of males.

\begin{tabular}{|c|c|c|c|c|c|c|c|c|}
\hline Sandfly species & $\begin{array}{c}\text { No of } \\
\text { sf }\end{array}$ & $\begin{array}{l}\text { No of } \\
\text { sf } / 100 \mathrm{pt}\end{array}$ & $\begin{array}{c}\% \text { of } \\
\text { total sf }\end{array}$ & 80 & $q 9$ & $\begin{array}{c}q q / \\
0 \delta+q q\end{array}$ & $\begin{array}{c}\text { No of } \\
\text { localities }\end{array}$ & $\begin{array}{c}\% \text { of } \\
\text { localities }\end{array}$ \\
\hline Phlebotomus (Phlebotomus) papatasi & 4 & 0.36 & $0.15 \%$ & 3 & 1 & 0.25 & 2 & $2.78 \%$ \\
\hline Phlebotomus (Parapblebotomus) sergenti & 12 & 1.07 & $0.46 \%$ & 9 & 3 & 0.25 & 5 & $6.94 \%$ \\
\hline Phlebotomus (Larroussius) neglectus & 450 & 40.00 & $17.21 \%$ & 351 & 99 & 0.22 & 48 & $66.67 \%$ \\
\hline Phlebotomus (Larroussius) perfiliewi & 129 & 11.47 & $4.93 \%$ & 101 & 28 & 0.22 & 30 & $41.67 \%$ \\
\hline Phlebotomus (Larroussius) tobbi & 213 & 18.93 & $8.15 \%$ & 175 & 38 & 0.18 & 39 & $54.17 \%$ \\
\hline Phlebotomus (Alderius) simici & 11 & 0.98 & $0.42 \%$ & 9 & 2 & 0.18 & 4 & $5.56 \%$ \\
\hline Total of Pblebotomus spp. & 819 & 72.80 & $31.32 \%$ & 648 & 171 & 0.21 & 54 & $75.00 \%$ \\
\hline Sergentomyia (Sergentomyia) dentata & 797 & 70.84 & $30.48 \%$ & 369 & 428 & 0.54 & 32 & $44.44 \%$ \\
\hline Sergentomyia (Sergentomyia) minuta & 999 & 88.80 & $38.20 \%$ & 484 & 515 & 0.52 & 51 & $70.83 \%$ \\
\hline Total of Sergentomyia spp. & 1,796 & 159.64 & $68.68 \%$ & 853 & 943 & 0.53 & 54 & $75.00 \%$ \\
\hline Total of sandflies & 2,615 & 232.44 & $100.00 \%$ & 1,501 & 1,114 & 0.43 & 63 & $87.50 \%$ \\
\hline
\end{tabular}

No of sf, number of sandflies; No of sf/ $100 \mathrm{pt}$, number of sandflies per 100 paper traps; $\%$ of total sf, percentage of the total number of collected specimens; $\delta \delta$, number of males; $q q$, number of females; $q q / \delta \delta+q q$, proportion of females; No of localities, number of localities in which they were found; \% of localities, percentage of the total number of localities

Table I. - Sandfly species on the island of Corfu. 


\begin{tabular}{|c|c|c|c|c|c|c|}
\hline \multirow[b]{2}{*}{ Sandfly species } & \multicolumn{2}{|c|}{$<25$ sf/100 pt } & \multicolumn{2}{|c|}{$25-100 \mathrm{sf} / 100 \mathrm{pt}$} & \multicolumn{2}{|c|}{$>100 \mathrm{sf} / 100 \mathrm{pt}$} \\
\hline & $\begin{array}{c}\text { No of } \\
\text { localities }\end{array}$ & $\begin{array}{c}\% \text { of } \\
\text { localities }\end{array}$ & $\begin{array}{c}\text { No of } \\
\text { localities }\end{array}$ & $\begin{array}{c}\% \text { of } \\
\text { localities }\end{array}$ & $\begin{array}{c}\text { No of } \\
\text { localities }\end{array}$ & $\begin{array}{c}\% \text { of } \\
\text { localities }\end{array}$ \\
\hline Pblebotomus (Phlebotomus) papatasi & 2 & $2.78 \%$ & 0 & $0.00 \%$ & 0 & $0.00 \%$ \\
\hline Pblebotomus (Paraphlebotomus) sergenti & 3 & $4.17 \%$ & 2 & $2.78 \%$ & 0 & $0.00 \%$ \\
\hline Phlebotomus (Larroussius) neglectus & 21 & $29.17 \%$ & 19 & $26.39 \%$ & 8 & $11.11 \%$ \\
\hline Phlebotomus (Larroussius) perfiliewi & 15 & $20.83 \%$ & 14 & $19.44 \%$ & 1 & $1.39 \%$ \\
\hline Phlebotomus (Larroussius) tobbi & 21 & $29.17 \%$ & 15 & $20.83 \%$ & 3 & $4.17 \%$ \\
\hline Phlebotomus (Alderius) simici & 3 & $4.17 \%$ & 1 & $1.39 \%$ & 0 & $0.00 \%$ \\
\hline Total of Phlebotomus spp. & 14 & $19.44 \%$ & 23 & $31.94 \%$ & 17 & $23.61 \%$ \\
\hline Sergentomyia (Sergentomyia) dentata & 10 & $13.89 \%$ & 10 & $13.89 \%$ & 12 & $16.67 \%$ \\
\hline Sergentomyia (Sergentomyia) minuta & 9 & $12.50 \%$ & 27 & $37.50 \%$ & 15 & $20.83 \%$ \\
\hline Total of Sergentomyia spp. & 7 & $9.72 \%$ & 22 & $30.56 \%$ & 25 & $34.72 \%$ \\
\hline Total of sandflies & 5 & $6.94 \%$ & 21 & $29.17 \%$ & 37 & $51.39 \%$ \\
\hline
\end{tabular}

No of localities, number of localities; \% of localities, percentage of the total number of localities.

Table II. - Distribution of the localities the sandfly species were found according to their relative density (number of sf/100 pt)

Table II shows the distribution of localities where the different sandfly species were found according to their relative density. Most of the species were found in low $(<25 \mathrm{sf} / 100 \mathrm{pt})$ or medium $(25-100 \mathrm{sf} / 100 \mathrm{pt})$ densities.

\section{DISCUSSION}

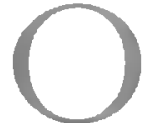

ur entomological results are generally in agreement with those obtained by MaduloLeblond (1983) about 15-17 years earlier. However, the relative density of almost all sandfly species was lower in our survey. This is probably due to the drop in the number of most sandfly species during August (Madulo-Leblond, 1983; Papadopoulos \& Tselentis, 1994) and the extensive use of insecticides, especially against the crop pests, during the last years. All three Pblebotomus spp. belonging to the subgenus Larroussius, $P$. neglectus, $P$. tobbi and $P$. perfiliewi, are considered potential vectors of $L$. infantum. $P$. neglectus, the most common Pblebotomus sp. on the island, is still the only sandfly species from which a $L$. infantum has been isolated in the Ionian islands (Léger et al., 1988; Garifallou et al., 1989). P. perfiliewi has been found infected with viscerotropic $L$. infantum in Italy (Maroli et al., 1988) and dermotropic L. infantum in Algeria (Izri \& Belazzoug, 1993), while $P$. tobbi has been infected experimentally by feeding on infected hamsters (Adler \&d Theodor, 1935).

The rarity of $P$. papatasi, vector of $L$. major and sandfly fever, in our captures is noteworthy. This species was considered by far the most abundant species in Corfu in human habitations (Stephanides, 1940). The scarcity observed may be due to the low number of domestic sites explored with the method of transects using castor-oil paper traps, as discussed in a previous article (Papadopoulos \& Tselentis, 1994). This species is nowadays found to be abundant only in Eastern Crete, Karpathos and Athens (Pesson et al., 1993; Papadopoulos \& Tselentis, 1994; Chaniotis et al., 1994).

$P$. sergenti, which was long suspected (Adler et al., 1938 ) but only recently proved to be a vector of $L$. tropica (Al-Zahrani et al., 1989; Guilvard et al., 1991), was rare in Corfu, where only few cases of CL have been recorded. This species is relatively abundant in the warmer and drier southern Ionian Islands and especially in Zakynthos (Pesson et al., 1984), the principal focus of CL in the region. It should be noted that $P$. sergenti, as well as $P$. simici, become very rare late in the season (Madulo-Leblond, 1983)

The sandflies of the genus Sergentomyia, captured in high numbers during our study, feed on reptiles and therefore have no epidemiological interest as vectors for human and canine leishmaniasis.

\section{REFERENCES}

ADLER S. \& THEODOR O. Investigations on Mediterranean kala azar. IX. Feeding experiments with Phlebotomus perniciosus and other species on animals infected with Leishmania infantum. Proceedings of the Roval Society $(B)$, $1935,116,516-542$.

Adler S., Theodor O. \& WitenberG G. Investigations on Mediterranean kala azar. XI. A study of leishmaniasis in Canea (Crete). Proceedings of the Roval Society (B), 1938, $125,491-516$.

Al-Zahrani M. A., Peters W., Evans D.A., Smith V. \& Ching CHIN I. Leishmania infecting man and wild animals in Saudi Arabia. 6. Cutaneous leishmaniasis of man in the 
south-west. Transactions of the Royal Society of Tropical Medicine and Hygiene, 1989, 83, 621-628.

Chaniotis B., Gozalo-Garcia G. \& Tselentrs Y. Leishmaniasis in the large urban area of Athens, Greece. Entomological studies. Annals of Tropical Medicine and Parasitology, 1994, 88 (6), 659-663.

Garifallou A., Hadjiantoniou M., Schnur L.F., Yuval B., Warburg A., Jacobson R.L., Pateraki E., Patrikoussis M., Schlein Y. \& Serie C. Epidemiology of human and canine leishmaniasis of the island of Zakinthos. In: D. T. Hart (Editor), Leishmaniasis. Plenum Publishing Corporation, 1989, pp. 1011-1015.

Guilvard E., Riolx J.-A., Gallego M., Pratlong F., Mahjour J., Martinez-Ortega E., Dereure J., Saidiki A. \& Martini A. Leishmania tropica au Maroc. III. Rôle vecteur de Pblebotomus sergenti. A propos de 89 isolats. Annales de Parasitologie Humaine et Comparée, 1991, 66 (3), 96-99.

IzR M.A. \& BEl_azzoug S. Phlebotomus (Larroussius) perfiliewi naturally infected with dermotropic Leishmania infantum at Tenes, Algeria. Transactions of the Royal Society of Tropical Medicine and Hygiene, 1993, 87, 399.

léger N., Gramicia M., Gradoni L., Madulo-leblond G., Pesson B., Ferté H., Bollanger N., Kili.ick-Kendrick R. \& KillickKENDRICK M. Isolation and typing of Leishmania infantum from Phlebotomus neglectus on the island of Corfu, Greece. Transactions of the Royal Society of Tropical Medicine and Hygiene, 1988, 82, 419-420.

Léger N., Pesson B. \& Madulo-Leblond G. Les phlébotomes de Grèce. Biologia Gallo-Hellenica, 1986, 11 (2), 165-192.
Madulo-leblond G. Les phlébotomes des îles Ioniennes. Thèse Doc. Sci. Pharm., Université de Reims, 1983, 218 p.

Mavrommatis $\mathrm{G}$. Le bioclimat de la Grèce. Relations entre le climat et la végétation naturelle. Cartes bioclimatiques (in Greek, with French summary). Dasiki Erevna, 1980, 1, 63 p. +3 maps.

Papadopoulos B. \& Tselentis Y. Sandflies in the Greater Athens region. Parasite, 1994, 1 (2), 131-140.

Pesson B., Léger N. \& Madulo-Leblond G. La leishmaniose en Grèce : Les phlébotomes des îles ioniennes et de la mer Egée. Annales de Parasitologie Humaine et Comparée, 1984, 59 (3), 277-296

Pesson B., léger N., Madulo-leblond G., Ferté H., Tselentis I., Papadopoulos B. \& Périeres J. Spéciation et vicariance chez les phlébotomes des îles grecques. Proc. 6th Int. Congr. Zoogeography and Ecology of Greece and the Adjacent Regions, Thessaloniki, 1993. Bios, 1994, 2, 233243.

Stephanides T. Corfu Phlebotomus (Dipt. Psychod.) found in human habitations. Bulletin of Entomological Research, $1940,30,303-304$.

Tzamouranis N., Schnur L. F., Garifallou A., Pateraki E. \& SERIE. C. Leishmaniasis in Greece. I. Isolation and identification of the parasite causing human and canine visceral leishmaniasis. Annals of Tropical Medicine and Parasito$\log \mathcal{Y}, 1984,78$ (4), 363-368.

Reçu le 2 décembre 1998 Accepté le 25 juin 1998

\section{Erratum}

Papaidopollos B. \& Tselentis Y. Sandflies in the Greater Athens region. Parasite, 1994, 1 (2), 131-140.

\begin{tabular}{|c|c|c|c|c|c|c|}
\hline Sandfly species & Nbr sf & $\%$ & $\sigma^{*} O^{*}$ & $९$ & 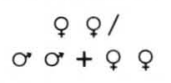 & $\begin{array}{c}\text { Nbr } \\
\text { local. }\end{array}$ \\
\hline Phlebotomus (Pblebotomus) papatasi & 541 & $18.40 \%$ & 414 & 127 & 0.23 & 40 \\
\hline Phlebotomus (Paraphlebotomus) alexandri & 30 & $1.02 \%$ & 28 & 2 & 0.07 & 9 \\
\hline Phlebotomus (Paraphlebotomus) sergenti & 13 & $0.44 \%$ & 10 & 3 & 0.23 & 3 \\
\hline Phlebotomus (Larroussius) neglectus & 1,002 & $34.08 \%$ & 915 & 87 & 0.09 & 55 \\
\hline Phlebotomus (Larroussius) tobbi & 182 & $6.19 \%$ & 163 & 19 & 0.10 & 27 \\
\hline Phlebotomus (Alderius) simici & 50 & $1.70 \%$ & 46 & 4 & 0.08 & 16 \\
\hline Sergentomyia (Sergentomyia) minuta & 1,122 & $38.16 \%$ & 747 & 375 & 0.33 & 40 \\
\hline Total & 2,940 & $100.00 \%$ & 2,323 & 617 & 0.21 & 64 \\
\hline
\end{tabular}

Table I. - Nbr sf, number of sandflies; \%, percentage of the total number of collected specimens; KK, number of males; $\Lambda \Lambda$, number of females: $\Lambda \Lambda / K K+\Lambda \Lambda$, proportion of females; Nbr local., number of localities they were found. 